\title{
Model Of Sugar Industrial Waste Management Based On Cleaner Production (Case Study: Sei Semayang Plantation and Sugar Mill)
}

\author{
Siti Mardiana ${ }^{1}$, Retno Widhiastuti ${ }^{2}$, Sumono $^{2} \&$ Luqman Erningpraja ${ }^{3}$ \\ ${ }^{1}$ Medan Area University, Medan, Indonesia \\ ${ }^{2}$ Postgraduate School, Sumatera Utara University, Medan, Indonesia \\ ${ }^{3}$ Riset Perkebunan Nusantara, Bogor, Indonesia \\ mardiana@uma.ac.id
}

\begin{abstract}
Controlling the amount and level of sugar industry waste must be done carefully, ranging from sugar cane harvesting in the field to the processing of cane into sugar mill. The aim of this research is constructing model and getting strategy and policy of sugar industry waste management based on clean production using dynamic system. This research was conducted at Sei Semayang plantation and sugar mill, PTPN II, North Sumatera in January until July 2013.Dynamic model system of waste management based on clean production was analyzed using Powersim program, license by sofware house Powersim ${ }^{\text {tm }}$, USA. The research shows Dynamic model of sugar industry waste management can be done by combining environmental subsystem model and socioeconomical subsystem. The scenario and policy of sugar industry waste management based on clean production results in waste minimilization, production process efficiency and increase of agricultural contribution, that it increases the surrounding community's income and involvement, and the company's income.
\end{abstract}

Keyword: sugar industry; waste management; clean production; dynamic system

\section{Introduction}

Besides giving a positive impact, sugar industry potentially giving a negative impact as well. Those things related to the too much result of solid waste, liquid gases and air emission. If there is no proper handling for those wastes, then sugar industry will face the challenging of environmental pollution because of resulted waste.

Some sugar industry activities has been implementing clean production such reutilizing resulted wastes, but still less optimal. Although cane bud is so potentially to convert to be animal feed, but the number of it utilization is relatively low $(3,4 \%)$. This case is caused of the decrement of top cane palatability if it is dried by sun shine, while exported one generally dried by drying machine, so it keep green and smell sweet (Setyawati, 1993). Plantation waste, blotong and dust contains high organic matters that can be used to create organic fertilizer, because it can increase production and prevent environmental pollution occurred. Research result report that decomposition and accumulation of blotong, vinasse and plantation waste affect a positive impact for organic need in cane production increment (Ou Yang et al., 2004; Lu, 2007; Zhu et al., 2007). But the utilizing of blotong for bio compost is also still low in used by farmers and sugar industry because inorganic compost is more realistic in increasing cane production. It suit with the research of Syafruddin and Astuti (2007) which explain that bio compost function just for soil enrichment, it indicates the result after long term period in use.

Clean production can be used as a model of environment management that forwardinghigh efficiency in an industry. Clean production implementation will be an advantage for industry because it can decrease production cost, economize and environment performance is better. Clean production implementation in an environmental sound industrial area (Purwanto, 2005). As well as that in point of view of Indastri and 
Fauzi (2009) explained that clean production is needed as a strategy in synergizing environmental protecting effort with building activities or economic growth, preventing environmental pollution, keeping and strengthen economic growth for a long term, preventing environmental degradation process and utilizing natural resource and strengthen the product bargaining position in international market.

Therefor optimization of waste management implementation such reduce, reuse and recycle is needed by arranging the model or designing sugar industrial waste management based clean production by reducing and utilizing waste through increasing employer engagement or citizen that can increase citizen income, company and local economy. System analysis is formulated based on management perception and people around mill about clean production principle in waste management.

\section{Research Method}

This research is running on Sei Semayang Sugar Mill, PTP Nusantara II, North Sumatera, Indonesia, on January-July 2013. Dinamic system analysis is dynamic system analysis with Powersim program package. In license of software house Powersim ${ }^{\mathrm{tm}}$, located in 1800 Sunrise Valley Drive, Suite 1400, Reston, VA 20191, USA. Based on founded model, the scenario and next 20 years simulation are created; the best scenario will be selected. This research is done with some steps, namely: 1) Problem formulation is created based on black box result approach and factual condition of study result that combined with theoretical concept from many literatures that is described in to inputoutput chart of industrial waste management, 2) Waste model management arranging created by using causal loop model structure based on correlation between amount and fractions that influence waste production of cane harvest, sugar management efficiency, waste management amount and production and waste utilizing level, 3) Evaluation and validation model completed with factual data from cane plantation and Sei Semayang Sugar Mill, PTPN II, North Sumatera, it does with two manners, those are: Absolute Mean Error (AME) and Absolute Variation Error (AVE), 4) Arranging scenario and formulating the policy.

\section{Result and Discussion}

In creating dynamic system model, started with problem simulation based on requirements analysis which has been done through problem identification periodically. Problem identification steps are done based on perception analysis and also employer and citizen preference and discussion result with the expert and literature searching. The combining in concept of clean production is reflected by amount of engaging aspect such human resource, financial, management and environment. Clean production strategy emphasize the effort of continuity and integrity of environment management. The successfulness or achievement of environment management target is not the end of the effort but it become an input of next environment management effort.

Then, general frame system that is the next step of problem formulation on sugar industry waste management based on clean production created by causal loop diagram to indicate variable or dominant aspect on sugar industry management based on clean production

\subsection{Problem Formulation}

General frame of sugar industry management based on clean production is started by creating causal loop diagram in two subsystems, those are environmental subsystem and social and economy subsystem. 
Model Arrangement

Based on problem formulation and creation of system general frame, then specifically and focus dynamic model building design is created which contains of environmental subsystem and social economy model subsystem which use powersim program.

Integrity model of sugar industry waste management based on clean production combine between management based on environmental aspect, social economy aspect and variables influence on subsystem model, it is served on stock flow diagram available on figure 1 .

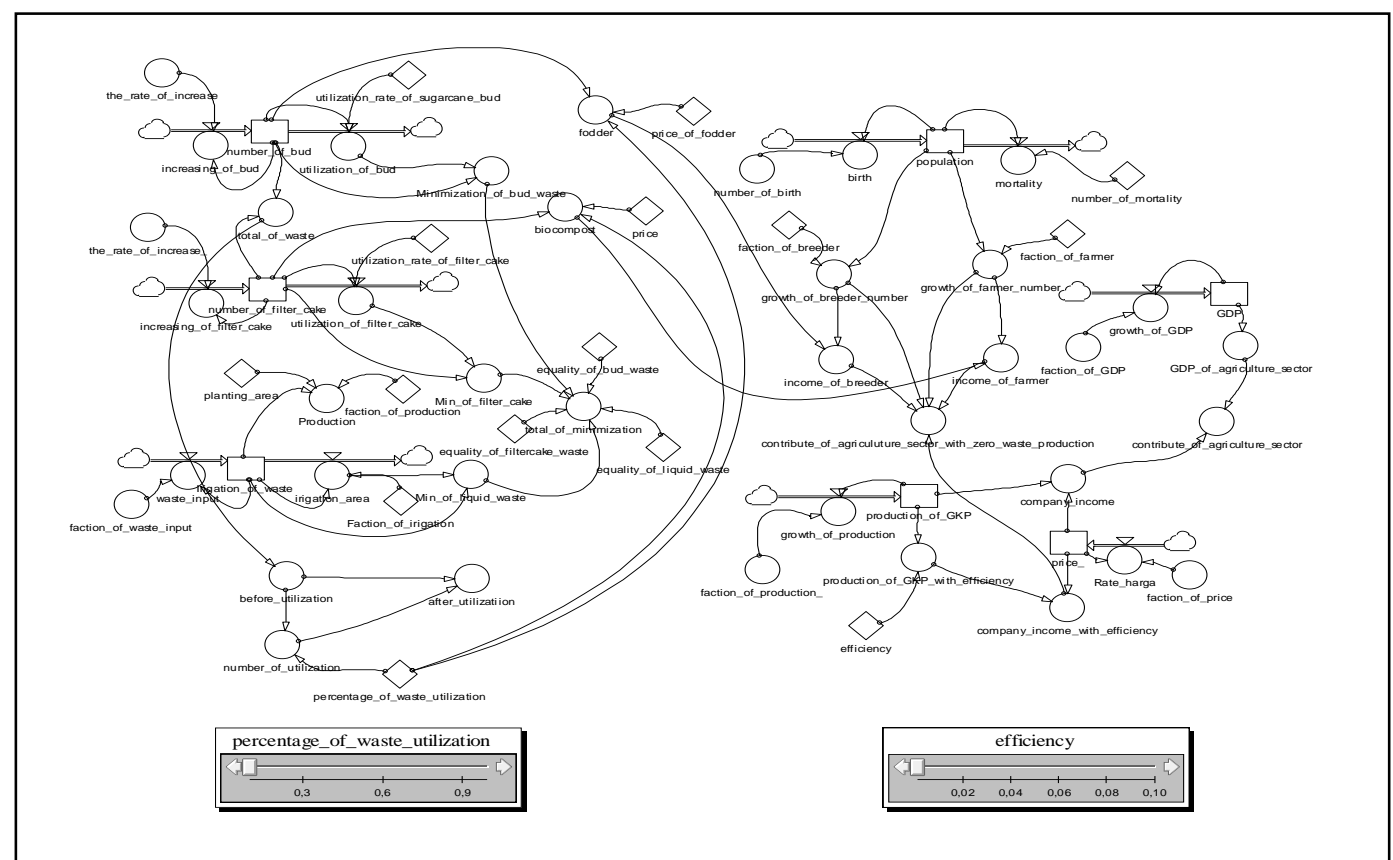

Figure 1. Integrity Model of Sugar Industry Waste Management Based on Clean Production

\subsection{Simulation and Validation Model}

Validation process is proposed to examine subsystem model that is arranged to know whether the model has satisfying of time accuracy in its application scope, consistency with planned destination of model creator (Salim, 2009). According to Sargent (1998), The used attribute in validation process is so much infected by used system condition in that model, whether the model can be observed or not.

Verification and validation of sugar industry waste management based on clean production is done on Sei Semayang Sugar Mill, PTPN II North Sumatera. Validation value on amount of bud waste, AME value as $0,13 \%$ and AVE value as $0.6 \%$, while blotong waste based on AME value as $0.32 \%$ and AVE as $1.83 \%$. That value $<10 \%$, it means that factual and simulation value has complied acceptable boundary.

\subsection{Scenario and Policy Model}

Condition prediction of future factors is done by conditioning and combining compatible factors and remove incompatible factors so three scenario are founded namely: (1) Optimistic scenario (2) Modern scenario (3) Pessimist scenario.

Final result of scenario of environmental subsystem is waste minimizing by reutilizing waste such recycle of of the top cane into livestock fodder for cattle fattening. Blotong waste as bio compost and water waste as irrigation. Sei Semayang Sugar Mill 
waste minimizing scenario can be seen on figure 2. A relation or institutional system that can optimize scenario option in managing of waste based on clean production is needed to strengthen citizen position in reutilizing sugar industry waste.

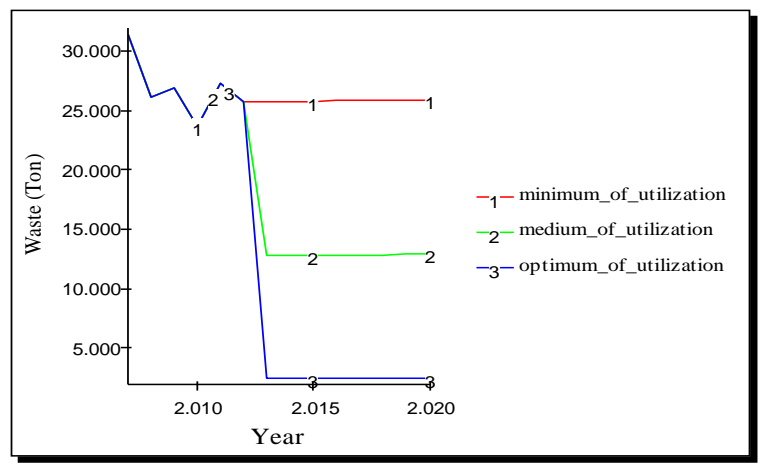

Figure 2. Minimizing scenario result of Sei Semayang waste

Efficiency of mill and waste recycling result economizing because of decrement of cost significantly so it can be the source of income. The increment production scenario of Sei Semayang can be seen in figure 3.

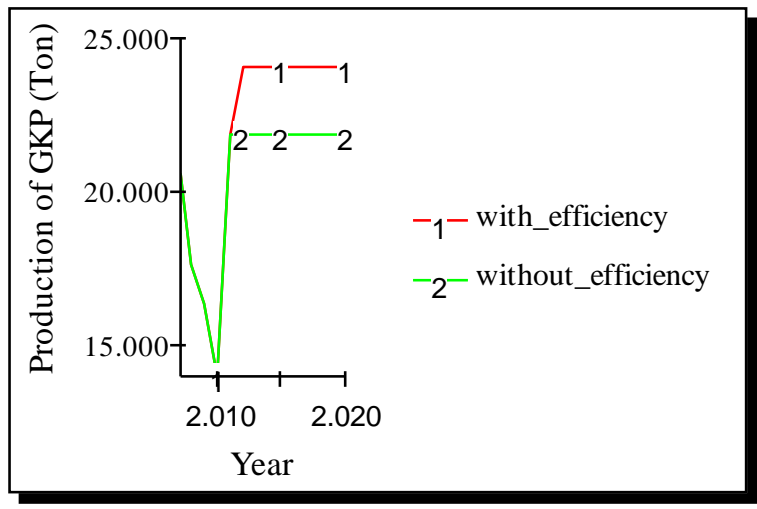

Figure 3. Efficiency scenario result on Sei Semayang production increment

Final result of integrity scenario of environmental and social economy subsystem is contribution increment of agriculture sector by utilizing waste such reusing cane bud as animal feed, blotong waste as bio compost and water waste as irrigation and mill efficiency increment. The increasing of farmers and cattlemen and company income, increase the contribution on agriculture sector in that place.

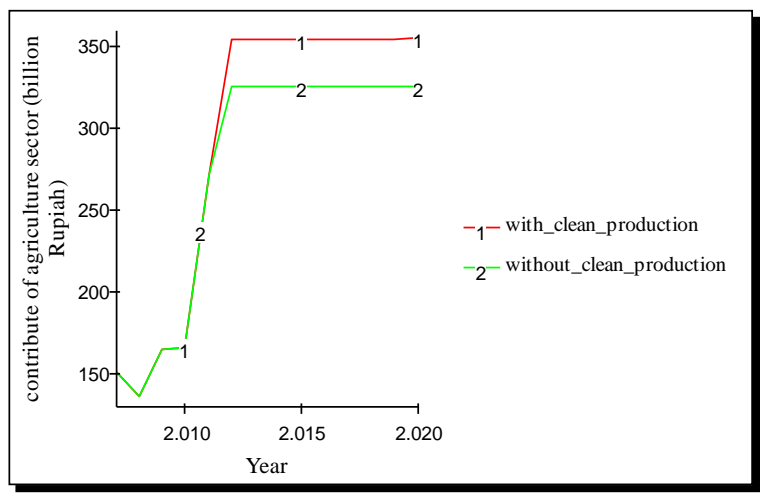

Figure 4. Scenario result of agriculture sector contribution in Kabupaten Deli Serdang waste management based on clean production. 
Increasing of agriculture and farming contribution scenario of Kabupaten Deli Serdang can be found on figure 4. To strengthen citizen position in reutilizing waste, it is need local government role that can optimize scenario option of waste management based on clean production, by giving stimulation, knowledge information aid or socialization and infrastructure of production.

Many countries have done innovative clean production activity by implementing corporation between government and industry. Tang dkk (1999) three innovative clean production activity in Taiwan, those are guidance or standard measurement of clean production performance, waste management and combination between industry waste management and healing system. The guidance or standard measurement of clean production performance is Waste Generation Index (WGI), Energy Consumption Index (ECI), and Hazard Index (HZI) for measurement development clean production and product design. Industry waste management combining and healing system are done by cheap industry waste management and higher efficiency level. The role of clean production that held in Taiwan affect significant result, so it reduce waste healing activity and waste management. Based on core business policy of Sugar Research Development Corporation (SRDC) in Australia, tells that to accelerate innovation and sugar industry sustainability in Australia is done by building people capacity to capitalize and to advance science and technology. Beside that they are guided on sugar industry sustainability by optimizing 3P combination namely Profit, Planet and People (Canegrows, 2013).

\section{Conclusion}

1.

Dynamic model of sugar industry waste management based on clean production can be done by integrating environmental subsystem model and social economy subsystem. Prediction in the year 2020, minimization of waste with $90 \%$ utilizing optimist scenario in Sei Semayang Sugar Mill location can decrease waste amount into 2.600,20 tons. Optimist scenario $10 \%$ increment with technology improvement on production process in Sei Semayang Sugar Mill is estimated may increase white crystal sugar production into $24.124,43$ tons. Optimist scenario 8\% increment of agriculture sector contribution in Kabupaten Deli Serdang, into 355,77 billion rupiahs.

2.

industry waste management based on clean production can be done by engaging more people by doing CSR program through cattleman group building in utilizing of top cane into livestock fodder, utilizing blotong waste as bio compost for cane plants and creating water waste generator for irrigation.

\section{References}

Indrasti, N.S. dan Fauzi, A.M. 2009.Produksi Bersih. IPB Press. Bogor.

Lu, H.D. 2007."Practice and exploration for commercial production of ecotypic high efficient sugarcane".Sugarcane and Canesugar, (5):21-25.

Ou Yang, Z.Y., Zha,o T.Q., Miao, H., Wang, R.S. and Wang, X. K. 2004. "Design for ecological industrial chain for sugar refining, alcohol distillation, energy provision and agriculture in Hainan". Acta Scientiae Circumstantiae, 24(5): 915-921

Purwanto. 2005. "Penerapan Produksi Bersih di Kawasan Industri". Makalah Seminar Penerapan Program Produksi Bersih Dalam Mendorong Terciptanya Kawasan Ecoindustrial di Indonesia. Diselenggarakan oleh Asisten Deputi Urusan Standardisasi 
dan Teknologi. Jakarta.

http://p3bd.vibet.org/files/Penerapan_Produksi_Bersih_di_Kawasan_Industri.pdf.

Diakses: 23 April 2011.

Sargent, R.G. 1998. Verification and Validation of Simulation Models.Proceeding of the 1998 Winter Simulation Conference. D.J.F. Watson. J.S. Carson and M.S. Manivannan, eds.

Setyawati, S. 1993.

"PemanfaatanPucukTebuSebagaiBahanPembuatanSilasedenganBahanPengawetTetes , DedakPadidanKombinasinyadengan Urea".(Tesis). Bogor: FakultasPeternakan, InstitutPertanian Bogor.

Syafrudindan A.D. Astuti. 2007. "StudiPengelolaanLimbahPabrikGula (StudiKasusPabrikGula PT. KebonAgungdi TrangkilPati)". JurnalPresipitasiVol. 2 No.1 Maret 2007, ISSN 1907-187X, 35-27.

Tang, G. Shin-Ru, Shen-Yann Chiu, Allen H. Hu, and Jyh-Shing Yang. 1999. Promoting Cleaner Production with Innovative Partnership Programs in Taiwan. Journal of Cleaner Production 7 (1999), 13-16.

Zhu, Q.Z., Li, Y.R., Huang, Z.Z., Wang, W. Z. and Lan, T.J. 2007. "Influence of vinasse of sugar factories on sugarcane yield and economic efficiency". Zhejiang Agricultural Science, (5): 520-523. 